\title{
ANALYSIS OF EARLY SIGNS OF EUTROPHICATION IN SUBARNAREKHA RIVER AT GHATSILA, JHARKHAND.
}

\author{
Swetaleena Mishra, Ravinder Singh \\ University Department of Zoology, \\ Kolhan University, Chaibasa, Jharkhand \\ Brajesh Kumar \\ Department of Chemistry, \\ Tata College, Chaibasa, Jharkhand
}

\begin{abstract}
Urbanization and industrialization are the terms that define the progress of the human civilization in today's world. But this so-called progressive approach of humans has caused a lot of damage to the nature and its resources. The present study deals with one of such major issues of environment today- "the eutrophication of rivers". The study reveals that the Subarnarekha river at the Ghatsila region of Jharkhand has been polluted to such extent by various types of organic and inorganic wastes that the present situation, if not controlled, will lead to its eutrophication. It is an alarming situation as this can have an adverse effect on the biodiversity of the river and also severe have implications on the human population.
\end{abstract}

Keywords - Algal bloom, Eutrophication, Fish kills, Hypertrophication, Macrophytes.

\section{INTRODUCTION}

The major cause of any type of pollution is the ever-increasing human population and over-exploitation of the natural resources. Eutrophication of rivers is a pertinent ecological issue as the freshwater bodies are adversely affected and slowly and gradually becoming dead, that is, the biodiversity will be totally lost and the water body develops more or less into a dead swamp that is of no use to any living organism.

Eutrophication is one of the most concerned and threatening ecological phenomenon that has caused the depletion of freshwater bodies on earth. Eutrophication may be explained as a process in which a water body is excessively enriched with inorganic salts and organic compounds that consequently alters the structure of the entire ecosystem. The major structural alterations include uncontrolled growth of algae (referred to as the algal bloom) and degradation of the physiochemical properties of the aquatic body that adversely affects the biodiversity of the aquatic ecosystem. Consequently, the flora and fauna become dead and the water body becomes a toxic swamp which slowly and gradually affects the entire population in its neighborhood.

Eutrophication, can also be described as a natural process of hypertrophication but nowadays, in wake of cultural eutrophication, only anthropogenic activities (directly or indirectly) are to be blamed for the ever-increasing rate of freshwater deterioration.

In the present study, emphasis has been given on finding the major causes that has given rise to a situation, where if proper measures are not taken at present stage, the river Subarnarekha, which is often called 'the lifeline of Jharkhand' will become an obnoxious and toxic water body. The river belt stretches through the main industrial areas of Ranchi, Jamshedpur and Ghatsila and the most relevant fact is that it passes through the entire mining belt of Jharkhand that includes the mining of heavy metals like Copper, Iron, Aluminum, and radioactive Uranium, mining sites of coal and many other precious stones etc., to count a few. Because of these mining activities and geogenic processes, the river is already in threat of heavy metal pollution that has been revealed in several studies by earlier researchers and also been found in this study. Besides, other major reasons have been identified and analyzed that shows Subarnarekha river at Ghatsila region is nearing eutrophication at its banks and soon this assumption may become a harsh reality.

\section{RELATED WORK}

In the year 2017-18, a research was carried out in the Subarnarekha river at Mau Bhandar and Galudih Barrage, Jharkhand to estimate the presence of different types of heavy metals in the river water. The analysis proved the contamination of the river with heavy metals like Zinc, Iron, Copper and Lead in higher concentration that poses threat of development of some respiratory and gastrointestinal diseases in the population as has been found by several research works 


\section{International Journal of Engineering Applied Sciences and Technology, 2019 \\ Vol. 4, Issue 7, ISSN No. 2455-2143, Pages 108-112 \\ Published Online November 2019 in IJEAST (http://www.ijeast.com)}

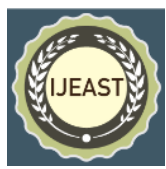

done earlier. Research work for remediation of heavy metals through plant sources is being carried out by the author and the work is in progress.

Estimation of heavy metals in river water-The water samples for estimation of heavy metals were collected in polypropylene bottles of 2 litres volume. To it, $1.0 \mathrm{ml}$ of concentrated nitric acid was added to prevent any type of microbial activity in it. These samples were tested for the presence of any heavy metals by Atomic Absorption Spectrophotometry.

\section{MATERIALS AND METHODS}

Description of site- The area of study lies in the domain of mining and industrial region of Jharkhand, Ghatsila. This belt of Ghatsila comprises of many industries like rice mills, soap and detergent factories, steel, iron rods and rubber tyres (for vehicles) manufacturing units. Besides, the river flows through the major mining sites of Copper, Uranium and Emerald. Though, the study area is not an urban township, this suburb has a huge population that directly depends on the river water for its daily needs like drinking water, farming, washing clothes and bathing. Just on the river bank is present the Hindustan Copper Ltd. Factory that directly discharges the factory output into the river water and deposits the residual slag on the river's bank. To add to this precarious situation, the villagers have made a cremation ground just on bank of the river. The area adjoining the cremation site has become a dumping ground for the nearby hospital wastes that includes both bio-medical and plastic wastes. A huge water-treatment plant is present at the riverside which further adds to the woe. The above cited reasons clearly suggest that the river stretch at this place is continuously being loaded with heavy amount of inorganic salts and organic compounds that is posing an alarming threat to the flora and fauna of the river, and also to the population residing in the neighborhood. Therefore, assessment of various point and non-point sources of eutrophication becomes extremely important.

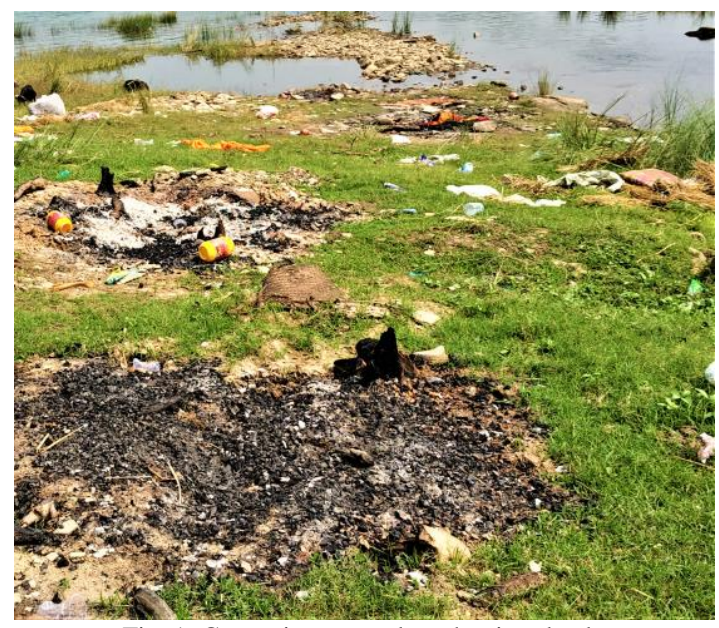

Fig. 1. Cremation ground on the river bank.

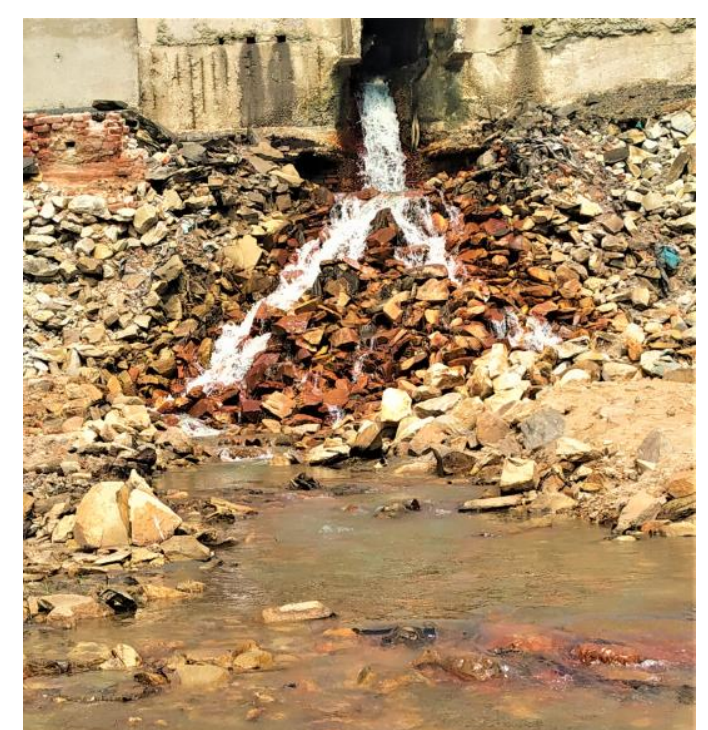

Fig. 2. Heated, acidic and toxic discharge from the factory outlet.

- Chemicals and apparatus required for testing physicochemical properties of river water- $\mathrm{pH}$ comparator, Mercury thermometer, Borosilicate bottle, Manganese sulphate solution, Alkaline iodide azide reagent, Concentrated Sulphuric acid, Burette, Conical flask, Phenolphthalein indicator, $0.02 \mathrm{~N}$ Sodium Hydroxide solution.

- Chemicals and instruments required for heavy metal analysis in the river water- Nitric acid, Zinc nitrate, Copper nitrate, Ferrous sulphate and Chromium chloride, Polypropylene bottles, Spectrophotometer.

Collection of water samples- The physiochemical properties of the river water were studied on the spot and these were analyzed by following the standard methods prescribed by the American Public Health Association (APHA, 1976). The water samples were collected during the morning hours between 7.30am- 8.30am for a period of twelve months from May'18 to October' 18 .

- Determination of $\mathrm{pH}$ in water sample- $\mathrm{pH}$ of the river water was determined by using a $\mathrm{pH}$ comparator and a comparator disc by colorimetric method.

- Determination of temperature of river water- A mercury thermometer having graduation from $0^{\circ}-110^{\circ}$ was used to measure temperature of the river water.

- Determination of dissolved oxygen in the river water- The dissolved oxygen in the river water was determined by Winkler's method. To $300 \mathrm{ml}$ of water sample $2 \mathrm{ml}$ of manganese sulphate solution was added followed by further addition of $2 \mathrm{ml}$ alkaline iodide azide reagent. The resultant solution was mixed thoroughly and then allowed to settle 


\section{International Journal of Engineering Applied Sciences and Technology, 2019 \\ Vol. 4, Issue 7, ISSN No. 2455-2143, Pages 108-112 \\ Published Online November 2019 in IJEAST (http://www.ijeast.com)}

down the precipitation. To dissolve the precipitate, $2 \mathrm{ml}$ of concentrated sulphuric acid was added. Then $200 \mathrm{ml}$ of this solution was taken in a flask to be titrated against sodium thiosulphate solution. The observations were noted just when the blue color of the solution became colorless.

- Determination of phosphate in river water- $50 \mathrm{ml}$ of water sample was taken in a flask and to it $2 \mathrm{ml}$ of ammonium molybdate was added and properly mixed. Then to this solution, $0.5 \mathrm{ml}$ of stannous chloride was added and it was diluted to $100 \mathrm{ml}$ volume. The intensity of this blue colored complex was measured by spectrophotometer at $650 \mathrm{~nm}$ against the reagent blank which corresponds to the amount of phosphate present in the water sample.

- Determination of nitrate in river water- To $50 \mathrm{ml}$ of water sample $1.0 \mathrm{ml}$ of hydrochloric acid and $1.0 \mathrm{ml}$ of sulfanilic acid reagent was added and mixed well. To it, $1.0 \mathrm{ml}$ of zinc chloride was added and mixed properly. Then $1.0 \mathrm{ml}$ of naphthylethylenediamine reagent was added followed by $1.0 \mathrm{ml}$ of $2 \mathrm{M}$ sodium acetate solution to the sample. The intensity of the red color thus obtained with the spectrophotometer at $550 \mathrm{~nm}$.

\section{RESULTS AND DISCUSSIONS}

The analysis of water from the Subarnarekha river at Ghatsila stretch shows that the water is more or less pale yellow in color and possess a metallic odor of iron. The yellowish color of the water is also due to the presence of iron that mostly mixes into the river water from the black-colored slag that is dumped from the HCL factory on the riverside.

The analysis of the water from the Subarnarekha river from my previous research clearly shows the presence of very toxic heavy metals in higher concentration than the accepted limits, that has been tabulated below. The $\mathrm{pH}$ of the river water is pointing towards slight acidification, as the $\mathrm{pH}$ range has been found to be $4.5-5.8$. The temperature of the water surface remains bit higher, about $34.5^{\circ} \mathrm{C}$ which may be due to the continuous discharge of water rinse from the industries present nearby and the water treatment plant located in this stretch. Huge loads of pollutants are recklessly added into the river due to various anthropogenic activities like washing clothes, bathing, religious rituals like immersion of idols and other offerings after festivals which has become a routine of the locales. Besides, sludges and biosolids, present in the sewage further add to the organic load into the river. It has been found in this study phosphates and nitrates are found in very high concentration in the river. The concentration of phosphates and nitrates in the river water was found in the range 0.85 $1.50 \mathrm{ppm}$ and $0.95-1.25 \mathrm{ppm}$ respectively which has severe implications on the river ecosystem and this alarming change in the river structure has been captured in the photographs taken from the study area. The clear sign of eutrophication is seen on the bank of the river Subarnarekha and thick growth of weed grass is also observed in the river water. It has been found that the rainwater and floods further increase the load of phosphates and nitrates in the river by leaching of fertilizers from nearby agricultural lands and the cremation ground on the riverside. The most important finding of the study indicates that the amount of dissolved oxygen in the river has been found to be less, ranging between 5.0-5.2 ppm. This result is self-explanatory for stepping-up of eutrophication process in the river. Due to the rapid blooming of algae and growth of weeds and other macrophytes, the sunlight fails to reach up to the photic zone and the vegetation of weeds die out quickly as the rate of photosynthesis is adversely affected. These dead and decaying plant matters are acted upon by the aerobic bacteria, resulting in severe deterioration of physiochemical properties of the water and drastic depletion of dissolved oxygen.

Table 1. Result of the physiochemical analysis of the river water.

\begin{tabular}{|c|c|c|c|c|c|}
\hline S/no. & Month & $\mathrm{pH}$ & $\begin{array}{c}\text { Dissolved } \\
\text { Oxygen } \\
(\mathrm{ppm})\end{array}$ & $\begin{array}{c}\text { Phosphates } \\
(\mathrm{ppm})\end{array}$ & $\begin{array}{c}\text { Nitrates } \\
(\mathrm{ppm})\end{array}$ \\
\hline 1 & May' 18 & 4.5 & 5.2 & 0.85 & 0.95 \\
\hline 2 & Jun' 18 & 4.9 & 5.0 & 1.20 & 1.25 \\
\hline 3 & Jul' 18 & 5.1 & 5.1 & 1.40 & 1.10 \\
\hline 4 & Aug' 18 & 5.5 & 5.0 & 1.50 & 1.20 \\
\hline 5 & Sep' 18 & 5.8 & 5.1 & 1.00 & 1.00 \\
\hline 6 & Oct' 18 & 5.0 & 5.2 & 1.50 & 0.98 \\
\hline
\end{tabular}

Table 2. Result of the analysis of the heavy metals present in the river water. Source "The estimation of heavy metals in Subarnarekha river at Mau Bhandar and Galudih Barrage, Jharkhand”, by S. Mishra, 2019.

\begin{tabular}{|c|c|c|c|c|c|c|}
\hline \multirow{2}{*}{$\begin{array}{l}\text { S/ } \\
\text { no } \\
\text {. }\end{array}$} & \multirow[t]{2}{*}{$\begin{array}{c}\text { Met } \\
\text { al }\end{array}$} & \multicolumn{2}{|c|}{$\begin{array}{c}\begin{array}{c}\text { Conc. Of Metal } \\
(\text { ppm) }\end{array} \\
\text { (At Mau Bhandar) }\end{array}$} & \multicolumn{2}{|c|}{$\begin{array}{c}\begin{array}{c}\text { Conc. Of Metal } \\
(\text { ppm) }\end{array} \\
\text { (At Galudih Barrage) }\end{array}$} & \multirow{2}{*}{$\begin{array}{l}\text { Permissi } \\
\text { ble } \\
\text { Conc. by } \\
\text { WHO } \\
\text { (ppm) }\end{array}$} \\
\hline & & $\begin{array}{c}\text { Pre } \\
\text { Monsoon }\end{array}$ & $\begin{array}{c}\text { Post } \\
\text { Monsoon }\end{array}$ & $\begin{array}{c}\text { Pre } \\
\text { Monsoon }\end{array}$ & $\begin{array}{c}\text { Post } \\
\text { Monsoon }\end{array}$ & \\
\hline 1 & Lead & 0.024 & 0.03 & 0.015 & 0.02 & 0.01 \\
\hline 2 & $\begin{array}{c}\text { Copp } \\
\text { er }\end{array}$ & 2.05 & 2.02 & 2.01 & 2.02 & 2.0 \\
\hline 3 & Iron & 0.03 & 0.04 & 0.01 & 0.03 & 0.2 \\
\hline 4 & Zinc & 3.2 & 3.3 & 2.9 & 3.1 & 3.0 \\
\hline
\end{tabular}

$1 \mathrm{ppm}=1 \mathrm{mg} / \mathrm{l}$ 


\section{International Journal of Engineering Applied Sciences and Technology, 2019 \\ Vol. 4, Issue 7, ISSN No. 2455-2143, Pages 108-112 \\ Published Online November 2019 in IJEAST (http://www.ijeast.com)}

$\%$ RSD $<2$

Based on the concentration range and abundance, the estimated elements may be ranked in descending order as $\mathrm{Fe}>\mathrm{Cu}>\mathrm{Zn}>\mathrm{Pb}[9]$.

The findings of this study vividly explain the inter-relationship among the different physiochemical properties of the freshwater ecosystem. Due to continuous discharge from the industries nearby and the water-treatment plant, the surface temperature of river water always remains higher than the normal temperature of the surrounding. This is one of the factors that directly affects the dissolved oxygen concentration of the river water as the atmospheric oxygen does not dissolve rapidly in warm water. The rapid growth of vegetation (algal bloom and growth of macrophytes) and their rapid death and decomposition often utilizes the available oxygen in the water and decreases the $\mathrm{pH}$ of the water body. This change in the water body has extreme implications on the aquatic ecosystem. The cultural eutrophication aggravates this process to such an extent that the entire fauna is killed and the aquatic body is described as 'dead'.

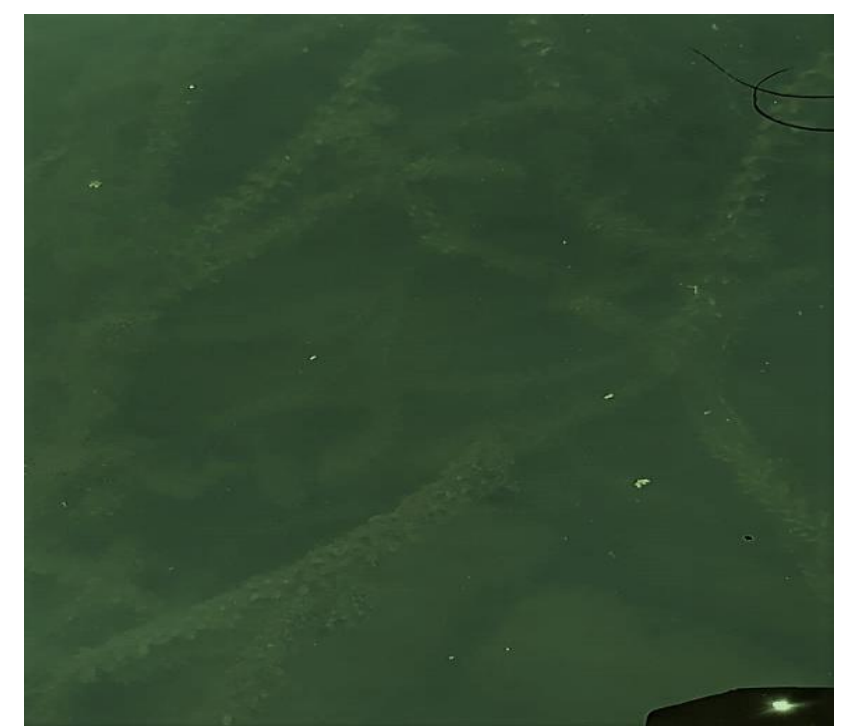

Fig. 3. Thick and wild growth of underwater vegetation obstructing sunlight.

\section{CONCLUSION}

All the above cited observations point to the nutrient enrichment and increased amount of organic pollutants in the river. The nutrient leaching and run offs from farm and waste disposal lands has resulted in exacerbation of eutrophication process.

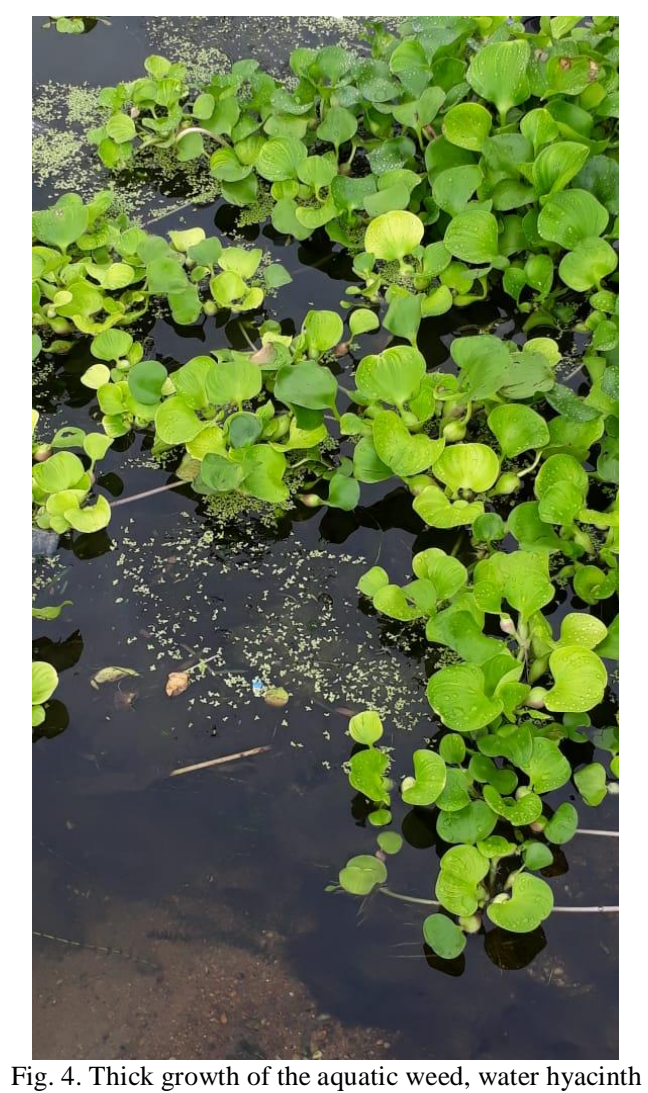

The phosphates and nitrates are very essential for the sustenance of the aquatic life. These nutrients may be present in particulate or in dissolved form. These phosphates and nitrates present in the environment often undergo conversion from one form to another through nutrient cycle. Naturally, the phosphates are present in the sewage and decaying matter as orthophosphates, which are utilized by different life forms for their growth. Chemically, the phosphates occur as polyphosphates that are major constituents of soaps, detergents, fertilizers and pesticides, which are later converted into orthophosphates. Nitrogen in the form of Nitrates is mostly present in sewerage.

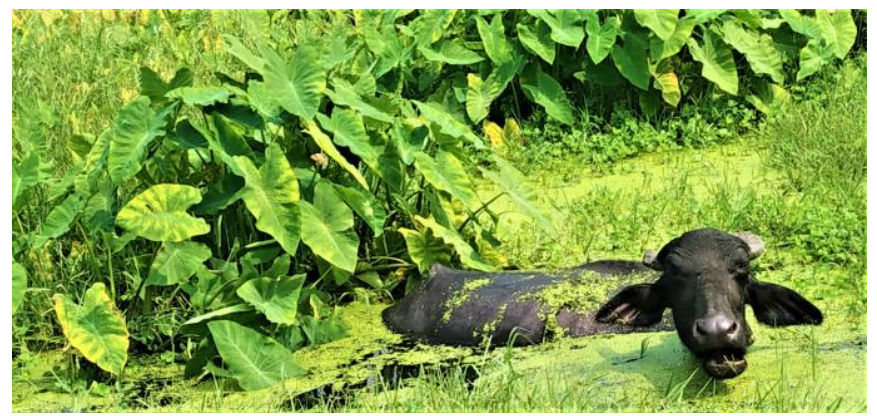

Fig. 5. Algal bloom and rapid growth of macrophytes depicting eutrophication. 


\section{International Journal of Engineering Applied Sciences and Technology, 2019 \\ Vol. 4, Issue 7, ISSN No. 2455-2143, Pages 108-112 \\ Published Online November 2019 in IJEAST (http://www.ijeast.com)}

If this process of overfertilization of the river with phosphates, nitrates and organic wastes continues at the present rate and no precautionary measures are taken the whole biodiversity of the river will be lost and the future generation will see this belt of Subarnarekha basin as an obnoxious and toxic swamp. But it is high time, proper measures be taken by the industries and Government bodies and strict laws are made to conserve the nature and its resources and also awareness among the people be spread through various programs to save the 'lifeline' of Jharkhand, the Subarnarekha river from dying.

\section{ACKNOWLEDGMENT}

The author is extremely thankful to the personnel the Hindustan Copper Limited factory for helping in carrying out the research around their site on the bank of river Subarnarekha, and the local people in helping in allowing to take the photographs at the cremation ground.

\section{REFERENCES}

1) Adakole, J.A. (2000). "The effects of domestic, agricultural and industrial effluents on the water quality and biota of Bindare stream, Zaria-Nigeria". Department of Biological Sciences, Ahmadu Bello University, Zaria, Nigeria, Ph.D Thesis, ( Pg. 256).

2) Anderson D.M., Cembella A.D. and Hallegraeff, G.M. (1998). "Physiological ecology of harmful algal blooms" Berlin; Springer-Verlag, $1^{\text {st }}$ Edn., (Pg. 647-648).

3) APHA. (1998). "Standard methods for examination of water and wastewater". American Public Health Association, Washington D. C., (Pg. 1000).

4) Bahekar, R., There, Y. (2013). "Seasonal variation in physico-chemical characteristics of Koradi lake, District Nagpur (India).” Indian Streams Research Journal, Vol. 3, Issue 2, (Pg. 1-5).

5) Colney, D.J., Paerl, H.W., Howarth, R.W., Boesch, D.F., Seitzinger, S.P.,and Havens, K.E. (2009). "Controlling eutrophication : nitrogen and phosphorus", Science 323 (5917), (Pg.1014-1015).

6) Durge, L.S., Dhammani, A.A., Chavhan, R. (2018). "Physico-Chemical characteristics of a fresh water pond of Ghugus, district Chandrapur, Maharastra (India)" International Journal of Scientific Research in Biological Sciences, Vol. 5, Issue. 3, (Pg. 59-64).

7) Goel, P.N., Khatavkar, A. Y., Kulkarni, A.Y. and Trivedy R. K. (1986). "Limnological studies of a few freshwater bodies in Southwestern Maharastra with reference to their chemistry and pollution". International Journal of Scientific Research in Biological Sciences, Vol. 5, No. 2, (Pg.79-84).
8) Howard, W.C. (1985). "Cycling and retention of nitrogen and phosphorus in wetlands". A theoretical and applied perspective. Freshwater Biology, 15, (Pg.391-431).

9) Mishra, S. (2019). "The estimation of heavy metals in Subarnarekha river at Mau Bhandar and Galudih barrage, Jharkhand." International Journal of Engineering Applied Sciences and Technology, Vol. 4, Issue 4, (Pg. 84-86).

10) Mitsch, W.J. and Gosselink, J.G. (2000). "The value of wetlands : importance of scale and landscape setting", Ecological economics 35 (1), (Pg.25-33).

11) O’Sullivan, P.E.O. (1995). Eutrophication", International Journal of Environmental Studies, Vol. 47, Issue. 3-4, (Pg. 173-195).

12) Sanchez S- Carrillo, Angeler D.G., M. Alvarez-Cobelas, R. Sanchez-Andres (2010). "Freshwater wetland eutrophication". Springer, (Pg.195-207).

13) Smil, V. (2000). "Phosphorus in the environment : Natural flows and human interferences", Annual review of energy and environment 25 (1), (Pg.53-88).

14) Smith, V.H. (2003). "Eutrophication of freshwater and marine ecosystems, a global problem", Environmental Science and Pollution Research 10(2), (Pg.126-139).

15) Umavathi, S., Longakumar, K., Subhasinai, P. (2007). "Studies on the nutrient content of Sulur pond in Coimbatore, Tamil Nadu". Journal of Ecology and Environmental Conservation, Vol. 13, Issue 5, (Pg.501504). 